\title{
植物ステロールとその類縁化合物の生理機能 Physiological Functions of Plant Sterols and the Related Compounds
}

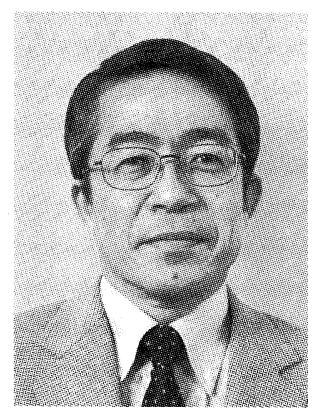

池田郁男

東北大学大学院農学研究科

T981-8555

仙台市青葉区堤通雨宮町 1-1

Ikuo IKEDA

Graduate School of Agricultural Science, Tohoku University

1-1 Tsutsumidori-Amemiyamachi, Aoba-ku, Sendai,

Miyagi, 981-8555, JAPAN

論文要旨：植物ステロールや植物スタノールは，血清 LDL-コレステロール濃度低下作用を有する。これ らの有効量は， $0.7 \sim 2 \mathrm{~g} /$ 日程度である。植物ステロール/スタノールは，小腸内腔で胆汁酸ミセルに溶解す ることにより，相対的にコレステロールの溶解を減少させ，コレステロール吸収を阻害すると考えられる。 植物ステロール／スタノールは吸収率が低く体内に蓄積せず，きわめて安全性が高い。これまで，上記掑取

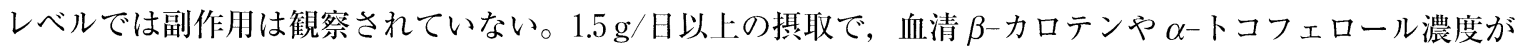
減少する場合があるが，これらビタミンが不足することはない。これらのことから，植物ステロール／ス夕 ノールは動脈硬化症予防に有効で，安全な食品素材と考えられる。

\begin{abstract}
Dietary plant sterols and stanols reduce LDL-cholesterol concentration through inhibition of intestinal absorption of cholesterol. Their effective doses are $0.7 \sim 2 \mathrm{~g}$ /day. Plant sterols/stanols are solubilized in the bile salt micelle and hence, relatively decrease micellar solubility of cholesterol. This may be the major cause to inhibit cholesterol absorption. Absorption and deposition of plant sterols/stanols are low and no side-effect was observed. In some higher doses, concentrations of serum $\beta$-catotene and $\alpha$-tocopherol can be reduced. However, deficiency of these vitamins has never been reported. In conclusion, plant sterols/stanols are thought to prevent atherosclerosis and to be safe dietary components.
\end{abstract}

Key words: plant sterol, plant stanol, cholesterol, phytostenone, $\beta$-carotene

\section{1 はじめに}

天然界には，多様なステロールおよびその類縁化合物 が存在するが, 大きくは動物性のコレステロールおよび 植物性の植物ステロールに分類できる。コレステロール は単一の化合物であるが，植物ステロールには多くの種 類がある（Fig. 1）。一般的な植物に普通に見られる主要 な植物ステロールは, カンペステロール, スティグマス テロールおよびシトステロールである。また，これらの 飽和型であるカンペス夕ノールやシトスタノールは比較 的普通に検出されるが，ステロールに比べると量的には

連絡者：池田郁男

E-mail : iikeda@biochem.tohoku.ac.jp
極めて少ない。植物ステロールは単一の化合物として存 在することは稀で, 通常はいくつかのステロールの混合 物として存在する。植物ステロールは植物性食品や植物 油に含まれるため，ヒトは日常的に $300 \mathrm{mg}$ 前後を摂取 しており，この量はコレステロール摂取量に匹敵する。 植物ステロールは栄養素ではなく，必ずしも摂取する必 要はない物質であるが，約 50 年前から血清コレステ ロール濃度低下作用が知られ，利用されてきた ${ }^{1,2)}$ 。ま た，植物スタノールは著者を含む菅野のグループにより その有効性が初めて明らかにされたが ${ }^{3.4)}$, 植物ステロー ルの水素添加により製造される。本総説では，植物ステ ロールおよびその類縁化合物の血清コレステロール濃度 低下作用やその他の生理機能について概説する。 


\section{2 血清コレステロール濃度低下作用}

\section{$2 \cdot 1$ LDL-コレステロール低下作用}

植物ステロールおよびその飽和型である植物スタノー ルを経口的に摃取すると，3 週間程度で血清コレステ ロール濃度が低下することは多くの臨床試験で確認され ている ${ }^{1,2)} 。 こ の$ 低下はLDL-コレステロール濃度の低下 であり，HDL-コレステロールはほとんど変化しない。 次項で述べるが，この作用は小腸からのコレステロール 吸収阻害に起因する。植物ステロール／スタノール投与 量と LDL-コレステロールの低下の程度は Table 1 に示 $す^{2)}$ 。このデー夕は欧米での 56 のヒト試験をまとめたも のであり，有効投与量の下限は $0.7 \sim 0.8 \mathrm{~g}$ /日程度である が $^{1,2)} ， 1.5 \sim 2 \mathrm{~g} /$ 日の摂取でより明確な効果が得られる。 われわれは日常的に植物ステロールを摂取していること から，有効投与量は日常掑取量の多少により変動すると 考えられる。

2 万人以上を対象としたイギリスでの疫学調査では, 日常的に食事から摂取する植物ステロール量と血清コレ
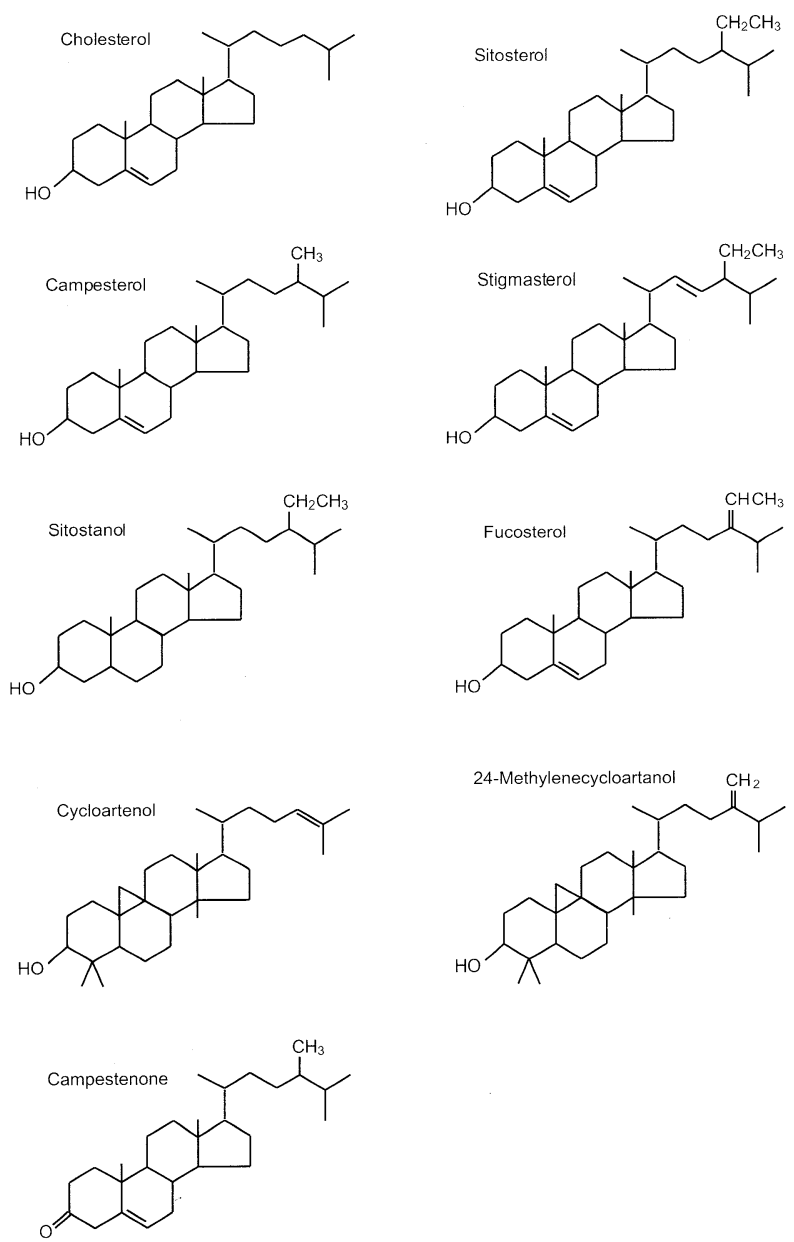

Fig. 1 コレステロールおよび植物ステロール，植物ステ， ンの化学構造
ステロール濃度には負の相関があることが報告されだ。 植物ステロール摂取量を 5 段階に分けた時，摂取量が最 も高いグループ（382〜 749 mg/日）では，最も低いグ ループ $(215 \mathrm{mg} /$ 日以下 $)$ よりも，LDL-コレステロール 濃度が男性で $5.4 \mathrm{mg} / \mathrm{dl}$ ，女性で $5.0 \mathrm{mg} / \mathrm{dl}$ 低かった。植 物ステロール摂取量が多いグループでは，総エネルギー 掑取量，総脂肪摂取量，飽和，多価不飽和およびモノ不 飽和脂肪酸摂取量, コレステロール摂取量, 食物繊維摂 取量がいずれも高かったことから，結果の解釈には注意 が必要であるが，植物ステロール摂取は少量でも LDLコレステロールを下げる一要因となることが示唆され る。

長期投与試験も多くはないが行われている。植物ス夕 ノール $1.8 \mathrm{~g} /$ 日を 1 年間続けた場合，LDL-コレステロー ル濃度は 8.5\%低下した ${ }^{6)} 。$ 一方，植物ステロール $1.6 \mathrm{~g} /$ 日，1年間摂取の場合は，5.9\%の低下が観察されてい $ろ^{7)}$ 。これらの結果から，植物ステロール／スタノール の効果には持続性があることが示唆される。

ヒト試験に用いられる植物ステロールの多くは大豆ス テロールであり，シトステロール 53〜 56\%，カンペス テロール 20〜 23\%，スティグマステロール 17〜 21\%程 度を含む混合物である。さらに，その他の植物油由来の 植物ステロールも用いられており，使用される植物ステ ロールの組成は試験ごとに異なる。実験動物の試験で は，各種植物ステロールの有効性には違いが認められる ことから，ステロール組成の違いは有効性に影響する可 能性がある。しかし，ヒトでは，組成の異なる植物ステ ロール間の直接的比較はほとんど行われていない。

植物ステロール／ス夕ノール含有食品の多くは，これ らを脂肪酸エステルとして利用している。遊離型の植物 ステロール／スタノールが油にそれほど溶解しないのに 対して，エステル型はある程度溶けることから，マーガ リンや植物油に添加することが容易となり，食品への応 用が広がる。現在では，ヨーグルト，ドレッシング，さ らには，ジュースなど飲料に添加した商品が開発されて いる。なお，すでに述べた植物ステロール／スタノール の有効量は，植物ステロール／スタノールとしての正味

Table 1 植物ステロールおよびスタノール摂取量と LDL-コ レステロール濃度低下の割合

\begin{tabular}{ccc}
\hline $\begin{array}{c}\text { 投与量 } \\
(\mathrm{g} / \text { 日 })\end{array}$ & 試験数 & $\begin{array}{c}\text { LDL-コレステロール低下率 }(\%) \\
(95 \% \text { 信頼区間 })\end{array}$ \\
\hline $0.7-1.1$ & 8 & $6.7(4.9-8.6)$ \\
$1.5-1.9$ & 13 & $8.5(7.0-10.1)$ \\
$2.0-2.4$ & 14 & $8.9(7.4-10.5)$ \\
$\geq 2.5$ & 21 & $11.3(10.2-12.3)$ \\
\hline
\end{tabular}

文献 2) 
の量であり，エステル型の量ではない。エステル型にな ると, 量的には多く必要である。

先に述べたようにヒト試験に利用される植物ステロー ルは，供給量の点から大豆由来が多く，通常は主にシト ステロール，カンペステロールおよびスティグマステ ロールを含有する。海藻に含まれるフコステロール ${ }^{81} や$, 米に由来するジメチルステロールであるシクロアルテ ノール，24-メチレンシクロアルタノールを含む植物ス テロール は通常の植物ステロールよりも効果が弱いこ とが報告されている（Fig. 1）。

\section{$2 \cdot 2$ 植物ステロールと植物スタノール}

われわれはラットやウサギを用いて，植物ステロール よりも植物スタノールは血清コレステロール濃度低下作 用が強いことを示した ${ }^{3,4)}$ 。ヒト試験は主にエステル型で 行われているが, 多くの臨床試験を総合すると, 植物ス タノールエステルは，植物ステロールエステルとほぼ同 等の効果と考えられている2)。しかし，ヒト試験におい て植物スタノールエステルと植物ステロールエステルと の直接比較は少ないため, 十分検証されているとはいい 難い。家族性高コレステロール血症の子供へのシトステ ロールおよびシトスタノールの投与試験では, シトス夕 ノールの方が血清コレステロール低下への有効性が高 かった ${ }^{10)}$ 。しかし，並行した投与試験ではなく，投与量 も両者で異なるなど, 定量的比較は困難である。O’Neill らは, いくつかの臨床試験を検証し, 植物ステロールエ ステルと植物スタノールエステルは 1 力月程度の摂取で は同等の LDL-コレステロール低下作用を示すが， 2 カ 月前後の摂取では, 植物ステロールエステル摂取の場

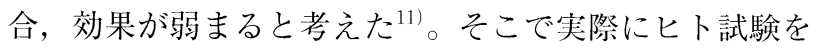
行い, 植物スタノールエステルと植物ステロールエステ ルの効果を調べたところ， $1.6 \mathrm{~g} /$ 日の摂取で 1 力月目ま では両者は同等の血清コレステロール低下作用を示した が, 2 カ月目では, 植物ステロールエステルでは, 1 カ 月目よりも上昇が見られ, 一方, 植物スタノールエステ ルではさらなる低下が認められた。植物ステロールエス テル摂取群では, 血中植物ステロールが増加し, 胆汁酸 合成の指標である $7 \alpha$-hydroxy-4-cholesten-3-one $(7 \alpha \mathrm{OHC})$ が低下した。一方, 植物スタノールエステル 摂取群では, 血中植物ステロールは減少し, $7 \alpha \mathrm{OHC}$ 変化しなかった。これらのことから, 著者らは, 体内に 取り込まれた植物ステロールがコレステロールからの胆 汁酸合成を抑制することで，血清コレステロール低下作

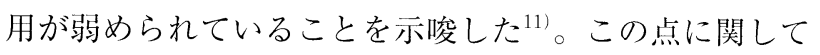
は, 他のヒト試験や実験動物等で確認されている訳では なく,さらなる研究を必要とする。

\section{$2 \cdot 3$ 遊離型とエステル型}

遊離型とエステル型はどちらが有効性が高いのであろ うか? ヒト試験では遊離型とエステル型を直接比較した 例は少ない。しかしながら，それぞれ単独で行った試験 を総合すると，遊離型とエステル型でほぼ同等の効果を 持つと考えられる。 $0.7 \mathrm{~g} /$ 日のシトステロールあるいは シトスタノール，あるいは $0.8 \mathrm{~g} /$ 日のシトスタノールエ ステルのヒト投与試験では，シトステロールおよびシト スタノールエステルでは血清コレステロールの低下が観 察されたが，シトスタノールでは低下が認められなかっ たという報告がある12)。コレステロール吸収率の低下も 前者では観察されたが，シトスタノール摂取では認めら れなかった。この試験では，投与量が有効性の見られる 最低レベルであり，血清コレステロール濃度低下作用は それほど顕著に見られた訳ではないので，普遍的な結果 とは思われない。遊離型とエステル型で効果に違いがあ る可能性については, 3·3で議論する。

\section{$2 \cdot 4$ 植物ステロールとコレステロール生合成阻害剤の 併用効果}

植物ステロール／スタノールとコレステロール生合成 阻害剂との併用効果は，いくつかの報告がある。生合成 阻害剂を摂取しているヒトに植物ステロール／スタノー ルエステルを与えると, さらに 7〜20\%程度の血清コレ ステロール濃度低下作用が得られることが報告されてい $3^{2.13)}$ 。コレステロール生合成阻害剤にさらに植物ステ ロール/スタノールを投与する被検者は，かなり血清コ レステロール濃度の高い家族性高コレステロール血症患 者である場合が多く，これらの試験での投与量は，2 $5.1 \mathrm{~g} /$ 日と多めである。植物ステロール／スタノールは コレステロール吸収を阻害することから，体内へのコレ ステロールの流入が減少するが，代償的に肝臓ではコレ ステロール生合成が活性化される2)。そのため, 植物ス テロール／スタノールの血清コレステロール低下作用は 弱められる。コレステロール生合成阻害剤はこの活性化 を抑えることから, 植物ステロールとの併用は有効性を 高めると考えられる。

\section{$2 \cdot 5$ 動脈硬化抑制作用}

われわれは，高コレステロール食摂取に伴うウサギの 大動脈のアテローム形成をシトスタノールとシトステ ロールは抑制し，シトスタノールがより有効であること を示しだ”。マウス，ウサギ，八ムスターに拈いて，植 物ステロール/スタノールは, 動脈への脂質の蓄積を抑 制することが報告されている 性心疾患の発症に及ぼす植物ステロール／スタノール投 与の影響を調べた研究は今のところない。しかし，コレ ステロール生合成阻害剂を用いた試験では, LDL コレ 
ステロールの $10 \%$ の低下は，5年間で動脈硬化性心疾患 の発症を 12〜20\%低下させることが示されており，植 物ステロール / スタノールの場合も同様の改善を期待で きると考えられる。

\section{3 血清コレステロール濃度低下作用のメカニズム}

\section{$3 \cdot 1$ 胆汁酸ミセルへのコレステロール溶解阻害作用}

植物ステロール／スタノールを摂取すると糞便へのコ レステロール排泄量が増加する ${ }^{2,3)}$ 。コレステロールを胃 内投与したラットの胸管リンパヘ吸収されるコレステ ロール量は，コレステロールと同時に植物ステロールを 与えると減少することから, 植物ステロールがコレステ

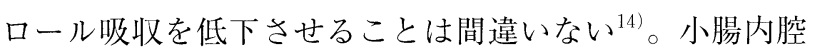
に存在するコレステロールは主に，食事，胆汁拉よび小 腸脱落細胞由来であり，一部はコレステロールエステル として存在する。コレステロールは食事由来のトリアシ ルグリセロール，リン脂質およびそれらの加水分解物, さらには胆汁に含まれるリン脂質や胆汁酸と共にエマル ションを形成する。コレステロールエステルは膵液のコ レステロールエステラーゼにより遊離型コレステロール と脂肪酸に加水分解される。遊離型コレステロールはリ ン脂質, リゾリン脂質, 脂肪酸, モノアシルグリセロー ルなどと共に胆汁酸混合ミセルを形成し溶解する。コレ ステロール吸収にとって，ミセルへの溶解は必須と考え られている。ミセルは直径 $5 \mathrm{~nm}$ 程度の粒子であり，小 腸上皮細胞表面を覆う不擋拌水層（unstirred water layer）を通過し，細胞表層の微䋐毛へ到達することが できる。ミセルは，微絨毛膜を通過できないため，コレ ステロールは単分子としてミセルから離れ，膜へと取り 込まれると考えられている。膜への取り込みは，以前は 濃度勾配依存の単純拡散によると考えられてきた。最 近，Niemann Pick C1Like1（NPC1L1）というたんぱ く質が見いだされ，これをノックアウトしたマウスで は，コレステロールや植物ステロール吸収が半減するこ

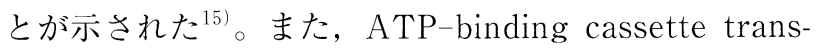
porter G5 (ABCG5) あるいはATP-binding cassette transporter G8（ABCG 8) はへテロダイマーで小腸上 皮細胞および肝臓に発現しており，植物ステロールやコ レステロールを小腸上皮細胞から小腸内腔へ, 肝蔵から 胆汁へと排泄し，吸収や体内蓄積を抑制すると考えられ ている ${ }^{15)}$ 。ABCG 5/ABCG8をノックアウトすると，こ れらステロールの吸収は増加する。取り込まれたコレス テロールは約 $90 \%$ がアシル CoA コレステロールアシル トランスフェラーゼ（ACAT）によりエステル化され， カイロミクロンへ組み达まれるが，コレステロールエス テルはカイロミクロンのコア (中心) 部分へ，コレステ
ロールは表層へと取り込まれる。カイロミクロンは小腸 上皮細胞から分泌され，リンパを経由して，血流へ入 る。

われわれは, in vitro で植物ステロールはコレステ ロールと同様に胆汁酸ミセルに溶解し，コレステロール の溶解を相対的に減少させることを見いだした ${ }^{14.16)}$ 。ま た，植物ステロールとコレステロールを㧺取したラット の小腸内容物から取りだした胆汁酸ミセル中のコレステ ロール量は，コレステロールのみ摂取した場合に比べ減

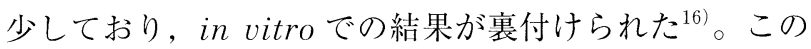
時，ミセルコレステロールの減少分は植物ステロールで 置きかえられていた。ラットの試験で, 小腸粘膜へ吸収 されるコレステロールの量およびリンパへ流入するコレ ステロールの量は，植物ステロールによるコレステロー ルのミセル溶解低下と同程度に起こった ${ }^{14,16)}$ 。一方，胆 汁酸ミセルに溶解した植物ステロールはミセルから小腸 粘膜へのコレステロールの取り込みに影響しなかった ${ }^{16)}$ 。 さらに，植物ステロールはACAT 活性に影響しなかっ たことから ${ }^{14)}$ ，小腸上皮細胞内でコレステロールのエス テル化を阻害し，吸収を抑制することはないと考えられ た。これらの結果を総合してわれわれは，コレステロー ルのミセル溶解の制限が，植物ステロールによるコレス テロール吸収抑制の主因であると結論した ${ }^{17)} 。$

ミセル溶解性の制限以外の作用機構を指摘する報告も ある。ABCG 5/ABCG 8 は Liver X receptor (LXR) $\alpha$ の標的遺伝子である。LXR $\alpha$ のリガンドとして酸化コレ ステロールが知られている。植物ステロールは化学構造 がコレステロールに類似しており，多量摂取した場合， 吸収された植物ステロールが酸化植物ステロールとな り，LXR $\alpha$ を刺激し, ABCG 5/ABCG 8 の発現を元進し て，コレステロール吸収を低下させる可能性が指摘され た ${ }^{18)}$ 。しかし，これは培養細胞のみの試験に基づいたも のである。マウスを用いた試験では，植物ステロール／ スタノール摂取は ABCG 5/ABCG 8 の発現に影響しな かった ${ }^{19)}$ 。たとえ多量に摂取しても植物ステロールの体 内量は，コレステロールに比較して極めて微量である。 したがって，生成する酸化植物ステロールの量も微量と 考えられる。このことから，酸化植物ステロールが LXR $\alpha$ のリガンドになると仮定しても，かなり強力な活 性を持たない限り，実質的にリガンド活性を発揮すると は考えにくい。

\section{$3 \cdot 2$ 植物ステロールと植物スタノールのコレステロー ル吸収に及ぼす影響}

ラットでの試験で高コレステロール食にシトステロー ルあるいはシトスタノールを添加した時, 糞便へのコレ ステロール排泄量は，シトスタノール投与で高くなる ${ }^{3)}$ 。 
Heinemann らは，ヒトを用いて，小腸灌流法でシトス テロールとシトスタノールのコレステロール吸収への影 響を調べ，シトステロールは $50 \%$ ，シトスタノールは 85\%阻害することを認め, シトスタノールの方が有効で あることを示唆した ${ }^{20)}$ 。小腸内容物中の胆汁酸ミセルへ のコレステロール溶解量は, シトスタノール摂食の場合

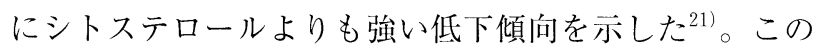
ように，コレステロール吸収を調べた試験では，植物ス タノールのほうが植物ステロールよりも有効性が高いこ とを示唆している。にもかかわらず，すでに述べたよう に植物ステロール／スタノールの血清コレステロール濃 度低下作用はほぼ同等と認識されている。このような矛 盾が何に起因するのかは明らかではないが，両者の有効 性を比較するためには，植物ステロールおよび植物ス夕 ノールを直接比較検討する厳密なヒト試験が必要であろ う。

\section{$3 \cdot 3$ 植物ステロール／スタノールエステルと遊離型の 効果の違い}

植物ステロール スタノールエステルは胆汁酸ミセル にほとんど溶解しないため, 遊離型に加水分解される必 要がある。これに関与する酵素は，抢そらく膵液中のコ レステロールエステラーゼ（コレステロールエステル加 水分解酵素）である。したがって，エステル型が小腸内 腔で速やかに加水分解されるかどうかがその有効性を左 右するように思われる。もし加水分解が遅れれば，遊離 型のほうが有効性は高いかもしれない。一方で, エステ ル型は油にかなり溶解する。油に溶解したエステル型は 周囲の油の加水分解に伴って自身も加水分解されること から, エマルションになりやすく, 胆汁酸ミセルへ溶解 しやすいように思われる。遊離型の場合は, 油への溶解 性が低いことから，エマルションになりにくく，胆汁酸 ミセルへの溶解が低い可能性が考えられる。このように 遊離型とエステル型には一長一短がある。すでに述べた が，ヒト試験では両者に明確な違いはないことから，長 所と短所が相殺して, 同様の有効性を示しているのかも しれない。ヒトを用いた試験で，植物ステロールとして $2.2 \mathrm{~g} /$ 日を与えた時, 遊離型とエステル型でコレステ

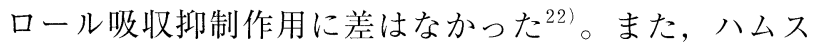
ターの試験でも，コレステロール吸収阻害に対して遊離 型とエステル型で差は認められていない23)。一方，われ われのラット試験では, 植物ステロールのオレイン酸エ ステルは，遊離型よりも有効性が低かった（未発表）。 このように，いくらか矛盾した報告が見られる原因は明 らかではないが, 動物種によりコレステロールエステ ラーゼの活性に違いがある可能性などが考えられる。な お， ハムスターの試験で, 植物ステロールのステアリン
酸エステルがコレステロール吸収を顕著に阻害したとす る報告があるが24)，この試験では食飭に5\%と多量添加 しており，植物ステロールの効果というよりは，難消化 性の食物繊維的な作用が起こったと推測される。

\section{4 植物ステロールの安全性}

\section{$4 \cdot 1$ 体内の植物ステロール /スタノールの影響}

植物スタノールは，食品への応用が開始されてからす でに 11 年，植物ステロールは 8 年が過ぎているが，副 作用や毒性は報告されていない。また，多量投与した実 験動物においても同様である。したがって，植物ステ ロール／スタノールはきわめて安全性の高い機能性成分 と考えられる。しかし，いくらかの懸念材料がないわけ ではない。

植物ステロールは難吸収性であり，比較的吸収率の高 いカンペステロールでも，吸収率は $10 \%$ 程度であり，

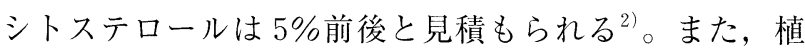
物ステロールはほとんど体内には検出されず，通常は血 清で $2 \mathrm{mg} / \mathrm{dl}$ を越すことはなく2)，1 mg/dl を越すこと も稀である。植物ステロールを摂取すると血清植物ステ ロール量は増加するが, 摂取量に依存するものの, 通常 の 2 倍を越すことはない。なお，血清中ではカンペステ ロールとシトステロールが主に検出され，カンペステ ロールのほうが多い。これは，カンペステロールのほう が吸収率は高いことによる。一方，植物スタノールは植 物ステロールよりもさらに吸収率が低く $1 \%$ 程度であ り，血清中では植物ステロールの 1/10 以下となる。ま た，植物スタノールは植物ステロールの吸収も抑制する ことから，植物スタノール摂取では，血中植物ステロー ル量が減少する2)

稀な遺伝的疾患である植物ステロール血症（phytosterolemia）では，体内に植物ステロールが蓄積し，血清 総植物ステロール濃度は数十 $\mathrm{mg} / \mathrm{dl}$ に達する ${ }^{25)} 。 こ の$ 疾 患患者では植物ステロールの吸収率が高く，胆汁への排 泄率が低い。これらの患者では，ABCG 5 あるいは $\mathrm{ABCG} 8$ に変異があることが知られている。ABCG $5 / \mathrm{ABCG} 8$ の変異に伴う機能低下は，小腸および肝臓か らの植物ステロール排洲能を低下させることから，体内 に植物ステロールが蓄積すると考えられている。高植物 ステロール血症患者はしばしば動脈硬化性心疾患を発症 する。しかし，これらの疾患患者では血清コレステロー ル濃度は正常な場合が多いことから，体内の植物ステ ロール濃度が高いことが動脈硬化症の原因の一つである

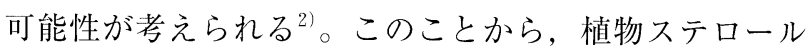
エステルを摂取して血中で増加する植物ステロールが, 動脈硬化症発症に影響する可能性が指摘されている ${ }^{26)}$ 。 
しかし，血中植物ステロール濃度と心臟血管系疾患の間 に関連があるかどうかは，一貫したデー夕はなく，結論 は得られていない27)。血中植物ステロール濃度の上昇を 問題視する研究者らは, 植物スタノールの優位性を強調 している。すなわち, 植物ス夕ノール摂取では, 血清コ レステロール濃度低下作用は植物ステロールと同様であ るが, 植物ステロールの吸収が阻害され, 血中植物ステ ロール濃度が低下する。このことから，植物スタノール のほうがより安全性が高いことを示唆している。

植物ステロールの吸収は，単純拡散㧍よび NPC 1 L 1 による取り込みおよび ABCG 5/ABCG 8 による排出のバ ランスによると考えられる。Igel らは，植物ステロール はコレステロール同様小腸上皮細胞へ取り込まれ，その 大部分が ABCG 5/ABCG 8 により排出されるとした ${ }^{28)}$ しかし，われわれは，植物ステロールは胆汁酸ミセルに 対する親和性が強いため，モノマーとして放出されにく く，吸収率が低いことを示唆した ${ }^{29)}$ 。し植物ステロー ルが一旦小腸上皮細胞へ取り达まれ，その後排泄される といった状況が連続的に起こっているならば，小腸上皮 細胞内での植物ステロール濃度は常に高くなるはずであ る。しかし，小腸上皮細胞内で吸収された植物ステロー ルがコレステロールと同程度に高くなることは観察され ない ${ }^{16,28)}$ 。したがって，少なくとも，植物ステロールが コレステロールと同程度に小腸上皮練胞へ取り込まれる とは考えられない。われわれは，ラットを用いた研究結 果から, 植物ステロールが小腸上皮細胞へ取り达まれる 量はきわめて少ないと考えているが30.31)，ABCG 5/ ABCG 8 による植物ステロール排泄量がどの程度かは, 今後の研究を待たねばならない。

\section{$4 \cdot 2$ 脂溶性ビタミン低下作用}

植物ステロール/スタノール掑取により, 血清の脂溶 性ビタミンの減少が観察される場合がある。このような 低下が観察されるのは, 投与量が $1.5 \mathrm{~g} /$ 日以上の場合が 多(2)。とくに， $\alpha$-トコフェロールと $\beta$-カロテンの低下 が問題視される。一方，レチノール（ビタミンA）やビ 夕ミン D は減少しない。 $\alpha-$ トコフェロールや $\beta$-カロテ ンは血清中では主に LDL と共に運ばれることから, 植 物ステロール／スタノール掑取で LDL-コレステロール が低下すると，これらもまた減少する可能性がある。 LDL-コレステロールの低下を考慮して計算すると， $\alpha-$ トコフェロールはほほ LDL-コレステロール濃度に比例 して低下するが， $\beta$-カロテンは LDL-コレステロールの 低下以上の減少が見られる ${ }^{2)}$ 。しかし， $\beta$-カロテンから 生成するレチノールの血中濃度は植物ステロール掑取で 滅少しない。 $\beta$-カロテンは吸収される際に，必要に応じ て加水分解されレチノールに転換される。したがって,
血中の $\beta$-カロテンはレチノールの貯蔵体と考えられ， その減少が直接レチノール不足につながるとは考えにく い。しかし，ビタミン A が不足しているヒトでは問題 を生じる可能性がある。

ヒトに植物ステロールとして $2.2 \mathrm{~g} /$ 日の遊離型㧍よび エステル型および $\beta$-カロテンあるいは $\alpha$-トコフェロー ルを与えた時，血中に出現するこれらビタミンの量は両 者とも植物ステロール摂取で低下した22)。ラット試験で は, 植物ステロールの摂取により血中, 肝臓の $\alpha$-トコ

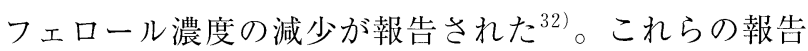
は， $\alpha$-トコフェロール抢よび $\beta$-カロテン共に植物ステ ロール撕取により吸収が抑制されることを強く示唆して いる。その機構として, 植物ステロール／スタノールは 胆汁酸ミセルへの $\beta$-カロテンの溶解を低下させること が報告されているが18)，十分な研究はない。

\section{5 その他の生理作用}

\section{$5 \cdot 1$ 前立腺肥大抑制作用}

20 年以上前から，ヒトにおいて植物ステロールを摂 取すると前立腺肥大症状が改善するという報告がある2)。 臨床的改善としては, 尿流量の増加と残尿量の減少であ る。しかし, 改善効果が認められた研究では, 投与量は $60 \mathrm{mg} /$ 日程度であり, 日常摂取している植物ステロール 量よりもかなり少ない。このような少量で改善作用が認 められる理由は今のところ明らかではない。

\section{$5 \cdot 2$ がん細胞増殖抑制作用}

マウス拉よび培養がん細胞に打いて，植物ステロール が大腸がん細胞増殖を抑制するといういくつかの報告が ある2)。しかし，その機構は明らかとなっていない。ま た，ヒトでの前向き研究では，植物ステロール摂取量と 大腸扮よび直腸がんの間に相関は認められていない ${ }^{33)}$ 。

\section{$5 \cdot 3$ 植物ステノンの生理作用}

植物ステロールの酸化物である植物ステノンは，ある 種の植物に含まれており，また，植物ステロールの掑取 により，腸内微生物によっても合成される。鈴木は，コ レステロールの酸化物であるコレスト-4-エン-3-オンは マウスの椇食を抑制し，内臓脂肪を低下させる作用を持 つことを示した ${ }^{34)}$ 。さらに種々の植物ステノンをラット に与え，いくつかの植物ステノンで効果を認めた。われ われは，カンペスト-5-エン-3-オン（カンペステノン， Fig. 1）をラットに与え影響を調べたところ，成長抑制， 腹腔内脂肪蓄積抑制, 血清および肝臓トリアシルグリセ ロール濃度低下作用を認めた ${ }^{35)}$ 。肝臟の $\beta$-酸化系醉素の 活性掞よび mRNA 発現は著しく上昇し，エネルギー消 費量は増加した。一方，肝臓の脂肪酸生合成系䤉素の活 性および mRNA は，リンゴ酸酔素を除いて，低下した。 
さらに，カンペステノンは peroxisome proliferator activated receptor (PPAR) $\alpha$ のリガンド活性があることが 明らかとなり，そのために $\beta$ 酸化系酵素の発現が上昇し たと考えられた。また, sterol regulatory element binding protein (SREBP)-1 mRNA の発現は低下したことか ら，これが原因で脂肪酸生合成系酵素の発現が低下した と考えられた。リンゴ酸酵素発現のプロモーター領域に はPPAR $\alpha$ および SREBP-1 に対する応答領域が両方存 在する。おそらく, PPAR $\alpha$ による発現誘導が SREBP-1 よりも強かったため, リンゴ酸酵素の発現は上昇したと 考えられた。肝臓灌流法を用いて調べたところ, カンペ ステノンを掑食したラット肝臓では, ケトン体産生が立 進し，トリアシルグリセロールとコレステロールの肝臓

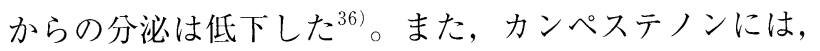
植物ステロール同様コレステロール吸収阻害作用があっ

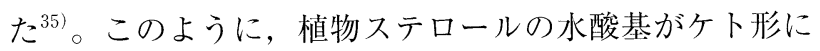
変わることで, 通常の植物ステロール様の作用に加え て, 内臓脂肪抑制作用が発現することが明らかとなっ た。ヒトでの試験は行われておらず，また，カンペステ ノンの体内代謝などが十分には明らかとなっていないが, ヒトでも内臓脂肪蓄積予防に有効である可能性がある。

\section{6 おわりに}

日本では植物ステロールは血清コレステロール濃度を 穏やかに低下させる食品素材として広く利用されてい る。一方，植物ス夕ノールは特定保健用食品の認可を受 けた商品はあるが，市販はされていない。植物ステロー ルノスタノールには医薬品のような劇的な作用はない が，安全性がきわめて高いことが利点である。日本人は 今後も動脈硬化症由来の心疾患が増加する可能性が高 い。植物ステロール／スタノールは心疾患を予防する一 助となる理想的な食品素材ということができる。

\section{文献}

1) 齋藤慎一郎, 池田郁男, 菅野道廣, 日本栄養 - 食糧学会誌, 55 (3), 177-89 (2002)

2) M.B. Katan, S.M. Grundy, P. Jones et al., Mayo Clin. Proc., 78, 965-78 (2003).

3) S.W. Andersson, J. Skinner, L. Ellegård et al., Eur. J. Clin. Nutr., 58, 1378-85 (2004).

4) T.A. Miettinen, P. Puska, H. Gylling et al., N. Eng. J. Med., 333, 1308-12 (1995).

5) H.F. Hendriks, E.J. Brink, G.W. Meijer et al., Eur. J. Clin. Nutr., 57, 681-92 (2003).

6) T. Kaneda \& K. Arai, Bull. Jap. Soc. Sci. Fish., 30, 589-93 (1964).

7) M.N. Vissers, P.L. Zock, G.W. Meijer et al., Am. J. Clin. Nutr., 72, 1510-5 (2000).
8) M. Sugano, H. Morioka \& I. Ikeda, J. Nutr., 107, 2011-9 (1977).

9) I. Ikeda, A. Kawasaki, K. Samezima et al., J. Nutr. Sci. Vitaminol., 27, 243-51 (1981).

10) M. Becker, D. Staab \& K.V. Bergmann, J. Pediatr., 122, 292-6 (1993).

11) F.H. O'Neill, T.A.B. Sanders \& G.R. Thompson, Am. J. Cardiol., 96 (suppl), 29 D-36 D (2005).

12) T.A. Miettinen \& H. Vanhanen, Atheroscler., 105, 217-26 (1994).

13) G.R. Thompson, Am. J. Cardiol., 96 (suppl), 37 D-39 D (2005).

14) I. Ikeda, K. Tanaka, M. Sugano et al., J. Lipid Res., 29, 1573-82 (1988).

15) F. Lammert \& D.Q.H. Wang, Gastroent., 129, 718-34 (2005).

16) I. Ikęda \& M. Sugano, Biochim. Biophys. Acta, 732, 651-8 (1983).

17）池田郁男, 日本農芸化学会誌, 65 (12), 1729-34 (1991).

18) J. Plat, J.A. Nichols \& R.P. Mensink, J. Lipid Res., 46, 2468-76 (2005).

19) T. Plösch, J.K. Kruit, V.W. Bloks et al., J. Nutr., 136, 2135-40 (2006).

20) T. Heinemann, G.A. Kullak-Ublick, B. Pietruck et al., Eur. J. Clin. Pharmacol., 40 (suppl.1), S 59-S 63 (1991).

21) I. Ikeda, Y. Tanabe \& M. Sugano, J. Nutr. Sci. Vitaminol., 35, 361-9 (1989).

22) M. Richelle, M. Enslen, C. Hager et al., Am. J. Clin. Nutr., 80, 171-7 (2004).

23) G.W. Meijre, M.A.J.J. Bressers, W.A. de Groot et al., Lipids, 38, 713-21 (2003).

24) H.E. Rasmussen, D.M. Guderian Jr., C.A. Wray et al., J. Nutr., 136, 2722-7 (2006).

25) T. Sudhop, D. Lütjohann, K. von Bergmann, Pharmacol. Therapeu., 105, 333-41 (2005).

26) T.A. Miettinen \& H. Gylling, Int. J. Clin. Pharmacol. Therapeu., 44, 247-50 (2006).

27) Y.M. Chan, K.A. Varady, Y. Lin et al., Nutr. Rev., 64, 385-402 (2006).

28) M. Igel, U. Giesa, D. Lütjohann, et al., J. Lipid Res., 44, 533-8 (2003).

29) I. Ikeda, K. Tanaka, M. Sugano et al., J. Lipid Res., 29, 1583-91 (1988).

30) T. Hamada, H. Goto, T. Yamahira et al., Lipids, 41, 551-6 (2006).

31) T. Hamada, N. Egashira, S. Nishizono et al., Lipids, 42, 241-8 (2007).

32) K. Nagao, M. Sato, M. Takenaka et al., Biosci. Biotechnol. Biochem., 65, 371-7 (2001).

33) A.L. Nomen, H.A.M. Brants, L.E. Voorrips et al., Am.J. Clin. Nutr., 74, 141-8 (2001).

34) K. Suzuki, J. Nutr. Sci. Vitaminol., 39, 537-43 (1993).

35) I. Ikeda, R. Konno, T. Shimizu et al., Biochim. Biophys. Acta, 1760, 800-7 (2006).

36) S. Tamaru, Y, Suzuki, M. Sakono et al., J. Nutr. Sci. Vitaminol., 52, 127-33 (2006). 